\title{
May the Volunteers Help Her Be Included into Society
}

\author{
Shuwen Wang
}

\section{Interview with Miss H's Parents}

H, female, born in 1989. Only child. Grade IV intellectual disability. Graduated from a special school-Miyu School in June 2006. Joined the Quyang Sunshine Workshop in Hongkou District of Shanghai in July 2006.

Interviewees: H's father, H's mother

Interviewer and writer: Shuwen Wang

Interview date: November 13, 2016 and January 11, 2017

Interview place: H's home, Shanghai

\section{Beloved Child Arrives by Natural Birth}

Q: Are you Shanghai natives?

H's mother: H's dad is Shanghainese, I'm from Zhejiang Province. He's a Shanghai native, I came from Ningbo years ago and became a new Shanghainese later.

H's father: Actually my family's roots were in Zhejiang Province until my parents moved to Shanghai before the "New China," before the year of 1949, when they were young, but my siblings and I were born in Shanghai and we identify ourselves as Shanghainese.

Q: How did you get to know each other?

H's mother: I lived in Ningbo, but came to Shanghai after I graduated. A relative of mine, who lives here, worked in the clothing industry and I've worked for him since I arrived. After some years, my husband and I were introduced to each other

\footnotetext{
S. Wang $(\varangle)$

Fudan University, 220 Handan Ro, Shanghai 200433, China 
by a mutual friend. We came from the same area and had a similar lifestyle, and we got married after we'd been seeing each other for around a year.

H's father: We were introduced by one of my business friends when I was a selfemployed worker, she was my wife's friend as well, she thought we might be a good match.

(He's smiling) She was very pretty and gentle when she was young. We had a good feeling about each other and after a while decided to start our own family. We got married in 1988 and we had H on 24 November 1989.

H's mother: Her precise time of birth was 5.17 p.m., in the afternoon on 24 November 1989. On that day, before sunrise, I felt some pain and according to the old saying, the shorter the interval of labor pain, the closer the time of delivery. We got up and went to the Fourth People's Hospital, the baby was 2 days overdue. When we arrived, the doctor checked the dilation of my cervix and said I was ready to give birth. It was a long and painful process. I'll never forget the pain that morning.

H's father: She went to the delivery room in the morning and gave birth in the afternoon; it wasn't that long, about $10 \mathrm{~h}$ more or less.

H's mother: But I felt I had been in the delivery room for a very long time. My husband was told to leave by the doctor after they sent me to the delivery room, and he left.

H's father: It was our first child and we didn't have any experience with this at all. The doctor checked my identity and said: "Now she's all right but you can't come in. So leave your number with me and go back home till I call."

Q: Were you worried about your wife?

H's father: Yes, of course, but there was nothing I could do, the doctor didn't let me stay with her.

H's mother: It was an old-fashioned delivery room, there were a number of halfnaked women sharing the space, so no family, especially men, were allowed to come in. The rule has changed recently, pregnant women get their own delivery room and the husbands are able to be there and support their wives.

H's father: She's right, there was more than one patient in the room, all of them were ladies and no man could go in.

H's mother: I gave birth around 5 p.m., and I was detained in the delivery area for another $2 \mathrm{~h}$ before the nurse sent me back to the ward. The doctor asked where my husband was because they couldn't find him. I thought he was in the doorway, but actually he'd gone back home. After $2 \mathrm{~h}$ under observation, a care worker came to me and gave me a big enamel cup of water to help with my digestion. I was only allowed back to the ward after I'd been able to pee.

Q: When did you return to the hospital?

H's father: I came back in the morning.

H's mother: It was the next morning.

H's father: I was waiting for the call from the hospital but didn't hear anything. I just thought my wife had there been for over a day, so I went to the hospital to check up on her, and the doctor told me when I arrived: "Your wife has given birth." For a newborn baby, it was hard to tell that anything was wrong with her, right? 
H's mother: Actually, the birth wasn't difficult, it was natural and both the baby and I were fine. Just before the birth, I was sick and vomited my breakfast, longan soup_-pushing for the baby upset my stomach. I was on my own and scared, the only thing I could do was follow the doctor's orders. Old people like to say, giving birth is a high-risk thing, like putting one foot in a coffin; some people hemorrhage and die, I was frightened.

I was so hungry after giving birth and even though I didn't know anybody in the ward, I still had to ask them for some snacks. I could have eaten a horse! The other patients were very nice and gave me some moon cake.

I was very upset when I saw my husband the next morning and thought I could have been dead and you wouldn't have known (crying). My husband arrived with empty hands, he asked me: "What do you want to eat?" I said: "Why didn't you bring any food with you? I was so hungry and had to ask people for food last night." So he went home to make some carp soup.

Back then, he couldn't cook, but nobody else was at home-his parents were retired, but were doing part-time work to help with the family's income-my husband had to ask a neighbor, an old lady who lived next door, how to make fish soup. Finally, he made the soup with her help.

Q: Was it tasty?

H's mother(laughs): Not bad, actually it was delicious.

Q: Did you live with H's grandparents at that time?

H's father: Yes, we didn't have our own place because there was a housing shortage. My daughter is now 28; 28 years ago, the Pudong New District Development hadn't begun.

H's mother: There wasn't a commercial housing market and people only got an apartment through their unit. My husband has four siblings, but he was selfemployed, so my parents-in-law said, "All the other children have got their own apartment except for you and your husband, come and live with us at least you'll have a home." During that time, when my daughter arrived, we also had financial difficulties, but my parents-in-law were very kind and helpful, they never asked us to pay for the accommodation. They never complained. We couldn't pay for imported milk powder either.

H's father: In those days, imported milk powder was very rare because international trade wasn't common.

H's mother: There wasn't anything like a baby nappy, people had to use old sheets to make diapers for their children.

Q: Did you have other relatives in Shanghai?

H's mother: My parents and all of my relatives were living in Ningbo. My husband had siblings who lived in Minhang, Baoshan, and Pudong District, but after they got married, they lived far away from our place.

H's father: We lived separately.

Q: Was $\mathrm{H}$ a healthy baby?

H's mother: She was very fit and hardly ever got sick, only an occasional fever or cold, nothing more serious than this.

Q: Compared with other children of her age, how was her physical development? 
H's mother: It was good, she developed well, there was no noticeable difference to other ordinary children of the same age. You can see she's a very big and tall girl. If you look at her pictures, she was very cute and pretty.

H's father: You can't tell she has a problem by looking at her face, you only realize this when she talks.

Q: How much did your life change when your daughter arrived?

H's mother: Our life definitely changed; we had a lot more family responsibilities.

\section{Her Math Was Poor and She Was Disliked by the Teacher}

Q: Do you know the reason for H's intellectual problems?

H's mother: No, we don't know. We really don't understand how we could have had a child that wasn't healthy. We'd heard that some children can inherit mental difficulties from their parents or grandparents, but we don't have a genetic problem in either family. I have one older sister and one younger brother and both of their sons are healthy. My daughter is the only one.

Some people caused problems for their children by using the wrong supplements or drugs during pregnancy, but we didn't have this problem either. Our daughter was healthy and normal when she was born. There was nothing wrong in the beginning.

But when she was very little, probably around 4 or 5 years old, she fell down the stairs. Her grandpa had brought her back from the nursery and carried her to the top of the stairs, but she lost her balance and fell down the stairs. She didn't bleed or have any swellings. They didn't tell us about this accident, we just heard about it from a neighbor sometime later.

When I asked them why they didn't tell me about this thing, my parents-in-law said nothing had happened to the girl, so they thought it wasn't worth mentioning to us. I said, "If you'd told me what had happened at least I could have taken her to the doctor and had her checked." This accident is the only thing I can think of, there is nothing else I can recall.

Later, I was told by some people the fall could have caused an internal injury and a problem without showing any external sign. We didn't have enough money to afford an MRI test at that time. We just guessed this accident might be the reason for her weakness.

Q: If you think the fall caused H's problems, did you have a problem with her grandparents after that?

H's mother: We complained occasionally. Sometimes I got annoyed with them when they spoiled the girl too much, it became hard to discipline her; at the same time, I couldn't really blame them, but I got angry with my daughter.

Q: Who looked after $\mathrm{H}$ when she was little?

H's mother: Her grandparents helped me to bring her up. After we had H, my husband and I had to go to work and her grandparents started helping me to look after her. In those days, both of us only worked every other day, so there was always one of us at home to take the girl with my parents-in-law. 
H's father: I was a taxi driver and shared the car with my partner, so I had a day off every 2 days.

H's mother: Her grandparents were quite elderly, and they couldn't do much more than feed the girl, my husband and I had to do most things; for example, we would pick up the girl when she went to nursery and school.

Q: So, basically it was your husband and you who looked after your daughter.

H's mother: That's right; we had the most responsibility, because we didn't dare to leave the child with them. My parents-in-law were quite old, especially the grandpa who was sick all the time. Also, I felt bad after my daughter's accident. We also disagreed with the way they spoiled her, they fed her too much. We had to think about her health and make sure the child didn't overeat. We also had to give tutorials at home for her homework, especially to improve her poor math skills.

$\mathrm{Q}$ : How old was $\mathrm{H}$ when she went to the nursery?

H's mother: When she was two, 24 months old. We took her to there every morning and picked her up in the evening. She wasn't good at controlling her bladder and wet herself at the nursery all the time. So we had to give the teacher extra pants to change her during the winter. We did this for her for years.

Q: When she was nursery age, did she behave differently from other children?

H's mother: There was nothing that I could tell at the time, but at the kindergarten, before she went to school, we realized her math was poor. My husband and I were too busy to sort out this problem and her grandparents didn't treat it seriously either. They said: "It's not a big problem, the primary school teacher will find a way to teach her."

Q: Did she have any problems with communicating with her classmates and teachers?

H's mother: She didn't talk very much. If the teacher asked: "Are you full?" My daughter would only nod her head while the other children would say: "Yes, I'm full." She only spoke if the teacher insisted that she answered and not nod her head. She tended to avoid speaking and communicating if she could just nod her head.

Q: Did she play with the other children?

H's mother: She liked to play with her classmates, but she looked like a hyperactive (ADHD) child, sometimes if she touched a boy, he might hit her back, then she would get scared.

Q: Did you think that was a problem?

H's mother: No, we didn't think so, and we didn't go out of our way to correct her.

Q: How old was she when she went to school?

H's mother: She started school when she was eight; the Xiangde Road Primary School which is very close to our place.

Q: Did you need to take her to school at that time?

H's father: Yes, we did. We usually took her to school; my parents helped us if they were free.

H's mother: At that time, my registered residence was still based in Ningbo and according to the law the children have to register at their mother's address. Later, my daughter became a non-Shanghainese student, so I had to pay a sponsorship fee 
to the school; 2000 yuan every academic year. Fortunately, her teachers liked her a lot, because she was cute and lovely. At the same time, she was hyperactive and undisciplined.

Q: That's what the teacher said at the time?

H's father: Yes. She would play on her own in the class. She didn't make any noise or disturb other students, she just played with her pencils and rubber. She was quiet, but she wasn't studying either.

H's mother: After a while, the teacher realized she was a nice and honest girl, but the other children didn't know that; if she touched somebody gently and unintentionally, the child might hit her back. The teacher usually let my daughter stay with her during the break in case she'd be bullied by other children. My daughter was very sweet; she massaged the Chinese teacher's shoulders when she said: "I'm so tired because you guys don't listen to me." The teacher thought my daughter's big eyes were very cute and liked to give her false eyelashes (she's laughing) to make her look like a pretty doll.

Q: How were her exam results?

H's mother: She wasn't good at exams. In the first year, her Chinese was nothing special, but her math was poor. Her math ability was very weak. In the class, everybody could do adding up very quickly except my daughter, she had to calculate with her fingers, even though it didn't' work sometimes. The math teacher didn't like my daughter and punished her by moving her with her desk to one side. It was a kind of discrimination.

H's father: All the other students got good results, $100 \%$ or slightly less; only my daughter got nothing!

H's mother: The day that the exam results came out, (laughing away) she was so naïve and told us, "I got an egg, a duck egg!"

H's father: Because she didn't write a single word.

H's mother: Even though the teacher told her to write her answers down, she wouldn't listen to him. The teacher said: "I really don't want to give up on her, but I can't help her if she doesn't write anything down."

Q: Did you give her private tutorials at home often?

H's father: She couldn't follow tutorials at all. Her Chinese wasn't too bad, because she could follow the Chinese copybook writing characters stroke by stroke.

H's mother: I kept her company when she did her homework until late at night, because she wrote very slowly and always put off doing it until the middle of the night. As parents, we were suffering as well. Having left school so long ago we'd already forgotten pinyin, so we had to relearn these things with my daughter and teach her afterwards. It was the same with math, after the teacher reported she was having difficulty, we started teaching her to calculate numbers with her fingers, but this doesn't work if the number is bigger than 10. Back in our time, my husband and I learned math in a very different way to my daughter. I had to study the whole thing again, but I have to be honest, she was falling behind with her math from her final year at the nursery and we didn't treat this problem seriously. It was partly our fault, but her low intelligence was also to blame. Other children wouldn't forget the formulas when you taught them, but my daughter could never remember them. 
H's father: There was a problem for sure. My daughter definitely has a low IQ.

H's mother: Later, the teacher told us: "We can't keep your daughter here any longer," and suggested that we send her to a special school. We struggled with this thing very deeply at the time. She was inferior at the ordinary school and humiliated by her classmates, even by teachers. We were quite upset by the teacher's attitude, to be honest. So, we thought, if the special school students didn't look down on her, she might get her self-confidence back.

H's father: The pace of study was slower at the special school, and although there is a stigma attached to the school's name, at least she can learn something there. Compared to her humiliating experience at the ordinary school, she would feel more relaxed when she was with other children with the same condition. So we had to face the truth. We thought through all of the details carefully and realized we had another choice, so we made the decision to send her to the special school.

Q: You struggled quite a lot with the idea of transferring her school, didn't you?

H's mother: I can't remember how much I've cried since we had her (she cries). From her first school year it had been a very tiring period for us trying to teach my daughter. So my husband and I discussed our situation and decided to send her to the special school. She might feel worse staying at the ordinary school. Even though we didn't mind giving gifts to her teachers hoping that they'd treat my daughter better, but it didn't help very much.

Q: Did you send gifts to her teacher?

H's mother: Yes, of course, we only did that for her. We used to buy gifts to hope the teacher would be more tolerant, but it didn't work.

Q: Was she happy at the Xiangde Road Primary School?

H's mother: She wasn't unhappy because she didn't understand the meaning of happiness. To be honest, she quite enjoyed her school life and she never worried about failing exams or such things. She was joyous and carefree.

H's father: She looked like she was living in another world-I don't care if I study or not, I just like to play with my things.

H's mother: It would be true to say she couldn't feel bad things, because she was quite inferior and didn't like to socialize with her classmates, but nobody wanted to talk to her either. The main problem was that the policy of allowing a disabled child into a "regular classroom" had not yet been implemented; otherwise my daughter would have had a chance to grow up with non-disabled children, learning normal social behavior and lifestyle from them. She didn't get a chance to develop in this way at the special school because it was full of disabled children and some of them had a worse condition than our daughter.

Q: Did the special school students behave differently?

H's mother: Definitely, the special school children behaved in a strange way.

H's father: Those children used to do some things that ordinary children would never do.

H's mother: Intellectually disabled people usually behave weirdly, screaming or something like that. H learned some bad habits from the school after she transferred to the new place; it took time to correct her afterwards. Sometimes I got angry with 
her when her manners were bad; my anger didn't stop her, it just made her angry. It was a very bad and rebellious cycle.

Q: Would you have insisted that she stayed in a regular class even if she thought she would have been humiliated or nervous?

H's mother: That's just what I thought.

Q: Except you worried about her learning some bad habits at the special school, did you worry about other things?

H's mother: She couldn't grow up, there was definitively no chance to develop her mind. Also, she couldn't learn normal things either.

\section{She Developed Slowly but She Was Happy and Carefree}

Q: Did your child have an IQ test?

H's mother: Yes.

Q: When?

H's father: One condition for joining the special school was the result of an Intelligence Test and we were told to go to the Mental Health Center of Tongxin Road to do the test. It's a special test designed to determine intelligence status and mental condition.

H's mother: To be honest, my daughter wasn't too bad. The Dean said her score was very close to the average rate.

Q: Do you remember the score?

H's mother: No, I can't recall the score after all this time, 65 or 70 I think.

Q: Do you remember the process?

H's mother: No, parents weren't allowed to observe the tests. The worker took her to a small test room and did the test with the doctor. We weren't allowed to know the details.

H's father: The parents couldn't go inside, but were given the result afterwards.

H's mother: They didn't let parents go to the test because the doctor wouldn't get a correct result if the parents helped their children. From what I understand, they gave different questions according to the child's age, if you were ten, you'll answer questions for that age. However, I believe her results were slightly lower than her real age.

Q: What's the difference between the special and ordinary school?

H's mother: The learning level and schedule are totally different.

H's father: The former is a special place for children who can't keep up with the pace of study or who've been left behind by the other students.

H's mother: Originally, this school was for deaf-mute children, but it changed to a special school when they were sent more and more intellectually disabled children. All the deaf-mute students at that time were transferred to a Shanghai deaf-mute school. Generally speaking, most district special schools are transformed deaf-mute schools.

Q: Did you keep driving her to school after she transferred to the special school? 
H's mother: No, she went to school by herself. In the beginning, I walked her to school and let her walk back by herself. We didn't feel comfortable letting her walk to school at first, so I told her go to school by herself, but followed behind. After she entered the school gate, I walked to the guardian and checked with him about $\mathrm{H}$ to make sure she had arrived safely. After that time, she started to go to school by herself.

Q: What did she learn at school?

H's mother: Chinese, math, PE, and music and other basic courses, but the big difference from the ordinary school is the special school doesn't have a learning schedule.

H's father: The teacher had to repeat the same thing until they learned it.

H's mother: The main textbook they used is a Chinese textbook, one book used through the whole academic semester, but they didn't learn very much. I have to say, those students weren't ordinary children, but the teachers had their own problems, too. The pace of teaching was too slow! Once they had a substitute teacher who had taught deaf-mute students before; he said our children could deal with a faster pace of teaching after he taught my daughter's class once. But for some reason, the teachers worked at a slow pace.

Anyway, they didn't have a teaching program, the teachers had an easy job, and the students didn't learn enough. At the same time, their textbook was much easier than the ordinary school. Later, a nice teacher told me: "You should teach your daughter to develop her handwriting. People prefer a person with beautiful handwriting than a diploma." I totally agreed with his idea.

Q: What was H's experience at the special school?

H's mother: She enjoyed that time very much, really enjoyed it there. She wasn't that happy when she was at the Xiangde Road Primary School where she was always under pressure socially and in her studies. We felt relaxed at that time as well, because the teachers were very friendly to the students.

Q: Did you help her with her homework after she went to the special school?

H's mother: Yes, we did. Actually, she understood most of the things that she learned at school.

H's father: Because the teaching schedule was slower.

Q: Did Mom do this?

H's mother: Yes, because my husband was usually very tired at the end of the day.

Q: Did they have exams?

H's mother: Yes, they did exams.

Q: What were her exam results?

H's mother: Her results weren't bad, pretty good actually.

H's father: The exams were quite simple.

Q: Did she get on with the other students?

H's mother: Yes, she was friendly with the other children, because they were all the same, so nobody looked down on anyone or the other way around.

H's father: They are the same kind of people.

H's mother: All of them are very naive.

Q: Did she talk to you about her school life? 
H's father: She didn't tell us anything when she was at the Xiangde Road Primary School.

Q: When did she start to talk about her school life?

H's father: When she was in her fourth year, after she transferred to the Special Education School-Miyun school. She started to tell us about some of the things that she learned that day, what class she attended, and so on. She could only tell us a brief story; if what happened that day was a long story, then she'd just tell us a small part.

H's father: At least she learned to talk about her daily experiences in a simple story at the new school, but at the ordinary school, she couldn't even remember her homework.

Q: Did she tell you anything else?

H's mother: If we asked her, she would talk about her lunch, what she had, and so on.

Q: Did you often ask her?

H's mother: We just asked some simple questions, such as what did you have for lunch, did you have some meat? She would answer "I had meat," but she couldn't tell us what kind of meat she'd had; she only knew that they had meat that day.

$\mathrm{Q}$ : When did she take the initiative to tell you something without being prompted?

H's mother: When she was in the seventh and eighth year at school, which had a nine-year education system. Especially, after she joined the Sunshine Workshop.

H's father: At dinner time, she liked to tell us what they'd had at lunch time and we didn't need to ask her anymore.

Q: Did she talk about anything else?

H's mother: Of course, she talked about other things too, but couldn't explain herself properly. Sometimes even we couldn't completely understand her when she tried to talk about something unusual or casual.

Q: Do you think $\mathrm{H}$ is improving gradually?

H's mother: Definitely, her speaking skills are getting better all the time, from rarely speaking and being unclear, to getting used to speaking more and more clearly. It's a kind of improvement, right? I remember once she was scared when her period started and I had to explain that it was a natural thing for every woman, including her and me. After that, I taught her to mark our "start" dates on the calendar: draw a red flag on the dates to remind us of our next period. I used this way to help her to sort out her problem with numbers. This kind of date is the most frequently marked date on our calendar.

Q: Red flag?

H's mother (she's laughing): Yes, that's right.

\section{If She Can't Change, then I Will Change Myself}

\section{Q: Did H ever lose her temper?}

H's mother: Yes, she was very stubborn when she was young and used to lose her temper sometimes. When she was angry, she might pull her hair or throw her 
schoolbag to express herself. Sometimes when she lost control of herself in the street, she would pull her hair or cry loudly and lots of people would stop and look at her. It was terrible, but she stopped doing this after a couple of years. She's much better now, and hardly loses her temper anymore.

Q: She pulled her hair and threw stuff?

H's father: She had a very bad temper.

H's mother: She would tell us that at that moment she just couldn't control herself at all. For example, she might get unhappy and lose her temper if we refused to give her something that she'd asked for, but she wouldn't get angry if she got what she wanted.

H's father: But she doesn't lose control anymore.

H's mother: No, because she's grown up. Sometimes I tell her: “Don't be angry, you'll look stupid."

Q: At what age did she have her worst tantrums?

H's father: When she was around 12 or 13.

Q: So that was her most rebellious time?

H's mother: It's hard to tell. It could be her age that made her rebellious. To be honest, we were young and in a bad mood at that time, too. Nobody wants a disabled child, but we couldn't speak out ourselves. My daughter was getting more stubborn and losing her temper very easily when we blamed her for something. It's in her character not to cry or stop if she's punished, she responds well to friendly persuasion rather than force.

Q: Under what circumstances would you lose your temper with your daughter?

H's mother: When she didn't obey me, of course. She was stubborn and this put me in a bad mood, she got very upset if I blamed her using harsh words, like calling her an "idiot." She doesn't like people to call her "idiot" and her pride is easily wounded. But we stopped using this word.

Q: Was she disobedient with you when she was younger?

H's mother: Not really, she wasn't too bad, but sometimes she lost control for no reason and she used to say: "I just can't control myself." Sometimes she would only have an angry face, but wouldn't make a sound. If I said to her: "Are you angry?" she'd reply: "I'm trying my best to control my temper." She responds well to kind words, she'll calm down if I say something nice to her.

$\mathrm{Q}$ : Can she control herself better now?

H's mother: It's possible, I usually tell her not to get angry if she gets unhappy. My daughter will explain: "I know I shouldn't be angry because I might be more stupid every time I lose my temper."

Q: What do you do when you lose your temper with $\mathrm{H}$ ?

H's mother: Nothing more than that and I usually regret it after I've blamed her.

H's father: We regret blaming her because she's different from normal people.

H's mother: It's our problem if we provoke her with strong words. These days, if she's angry, we usually try to calm her mood with kind words. It usually works. We keep learning from our experiences (smiles).

Q: Did Dad ever get angry with H?

H's father: Yes, it's happened. 
Q: What did you do?

H's father: I criticized her: "Why did you do this? Don't do it again."

Q: Was your tone quite tough?

H's father: She usually gets angry if you talk to her in a strong tone.

H's mother: Back then, she might change her mood if I criticized her dad. Sometimes she wouldn't eat if she argued with her dad and I could only get her to eat if I calmed her down with gentle words. She could go on this way for quite a long time, not eating if you didn't calm her down.

Q: What kind of things make you lose your temper?

H's father: I don't criticize her very often. It only happened if she went too far.

H's mother: H's anger was always triggered by criticism that she didn't like, so we decided to change our attitude to solve the problem. For example, she usually got upset if we said "you're stupid," so we stopped saying this. I started to explain myself in a different way: "H, it would be smarter, if you behave in a better way."

H's father: We changed ourselves because we realized she wasn't able to change.

Q: Have you had any minor problem with $\mathrm{H}$ recently?

H's mother: Very rarely, or just some small problems; for example, she likes to take coffee to her office even when I tell her that drinking too much coffee isn't good for her skin and makes her face spotty. I suggested she take some chrysanthemum tea instead of coffee, but she insisted on coffee and got upset with me, so I've let it go. I thought about this thing later, drinking coffee isn't a big deal, the only reason I stopped her is thinking about the consequences, but it's not an argument at all. Our relationship is pretty good these days.

Q: How about her relationship with her dad?

H's mother: They don't argue either.

H's father: I usually let her do what she wants to do.

\section{Taking Exercise Improved Her Intelligence}

\section{Q: Did H get involved with Special Olympics?}

H's mother: Yes, she did. The first time, the Special Olympics workers went to the Special School to elect suitable athletes in 2006. There were a certain number of games that every special school had to get involved with. Those workers thought $\mathrm{H}$ looked quite tall and strong, so they let her join in several games, like weightlifting and races. That year, $\mathrm{H}$ and other athletes went to the 2006 Special Olympic Shanghai Invitational Games for a week and lived in a hotel in the Zhabei District with volunteers. She won a gold medal and received a 500-yuan subsidy. So she used this prize money to buy chocolate for the teachers and volunteers (she smiles). After that, she joined Special Olympics in 2007. Actually, Special Olympics has some regular events every year, like the "Special Olympics Day," "Special Olympics Week," and "Special Olympics Month." My daughter usually takes part in these sport events.

Q: In 2007, what events did she compete in? 
H's mother: The $4 \times 100$ m relay and long jump, I guess. I wasn't there at that time, parents weren't allowed to go to the ground with them, they were accompanied by their schoolteachers.

Q: So they went to the competition with the teachers?

H's mother: That's right, they didn't live at home during the competition.

H's father: In addition to the teachers, there were also some volunteers who were college students.

Q: Did they have any pre-competition training for the Special Olympic Games?

H's mother: You mean collective training? They didn't have that. But they had PE teachers from the Special School to train them. These days, the training is supervised by the teachers from the Sunshine Workshop.

Q: Did they have weekend training then?

H's mother: She was a student, so the teacher trained them in normal school hours. Today, if we've been invited to join in the games, some teachers and volunteers supervise their practice. We train them for table tennis and bocce, at the weekend or when we're free. There's also some overtime training.

Q: Overtime training?

H's mother: For example, we used to borrow a school playground for training on Monday or Tuesday afternoons when those places were free. Sometimes, we trained with the students in Hongkou Park. We always find a way to practice before their competitions.

Q: What did you do in training?

H's mother: Before the competition, we let them practice table tennis for a long time every day. The teachers help them practice and count how many "goals" they score every time. There's a tiny hole on the table tennis table, they have to put the balls in the hole to score a goal.

H's father: They become skilled at the game through long practice.

H's mother: Yes, they have to concentrate on the target all the time.

H's father: For these children, the competition isn't the main thing, it's the participation that's the most important.

H's mother: They have to know how to play the game first. With bocce it's the same idea, they have to be smart to choose the right target and position, that's why they need plenty of practice.

Q: Does Dad get involved with their team training?

H's father: No, because most of the volunteers are female, you hardly see a man there. Usually the moms look after the practice and other events, so my wife works very hard.

Q: There are no dads at all?

H's mother: No, all of the children go to the events with their mothers. I quite enjoy practicing with her, actually, she can join in some competitions and I get exercise at the same time. Even if the competition is important, for me, the exercise is the best thing, because exercise helps her develop her intelligence, and develops her arm and leg coordination. Nothing is wrong with exercise, right? The parents are getting fit while helping their children practice. Sometimes, when we were dancing together, I felt I was becoming young again (she's laughing). The parents are learning a square 
dance right now and teaching the children afterwards. We learned the Xinjiang Dance the same way in the past. For me, it's a pretty nice thing to do.

Q: Did $\mathrm{H}$ ever complain that the training was too tiring?

H's mother: No, she never said that. She usually told us what exercise they did that day; practice was always necessary before the competition. After the Special Olympics World Games was held in Shanghai, there are many events. We won second place in this year's Intercity Invitational Tournament of the Sunshine Unified Run. Each team has 12 people running together, 6 special children and 6 volunteers; people stand in a line and tie their leg together with the teammate's next to them. The training was quite difficult, we fell down from time to time, but everybody had kneepads. For safety reasons, without the proper training, we couldn't practice this game on the ordinary ground, sometimes we had to practice on the lawn in the park. I'm one of the team's volunteers, so I trained and went to competition with my daughter.

H's father: All volunteers are unpaid.

H's mother: That's right, we're unpaid volunteers. The main purpose of this is to help these children get out of the home and be a part of society, but we like to join in some of the competitions if we can. The Sunshine Unified Run is an annual competition; we won second place this time, but we won first place last year. Usually the competition takes place at the Rehabilitation Center for the Disabled Persons in Songjiang District and our team hasn't missed this competition since the first year.

Q: Which competition is the most impressive for you?

H's mother: Definitely Special Olympics, because my daughter won a gold medal at this international event. This year, she and other children representing Shanghai went to the Intercity Special Olympics Day events on 15-18 July.

H's father: Sure, they represented Shanghai.

Q: Are you proud of your daughter's achievements?

H's mother: I'm very pleased for her. I'm always happy if my daughter is happy. The result isn't a big thing for her, she just enjoys the experience.

Q: Did she change after she became involved in sports?

H's mother: It's remarkable, my daughter became much happier! She's loves telling our guests: "Aunt, I won a medal." She also receives 200 yuan for participating.

Q: Could you tell me more about her practice in the side drum band?

H's mother: She joined the band in 2005.

Q: Where did you hear about this band?

H's mother: Two teachers in the band approached her. They said playing the side drum is good for improving her intelligence. I thought it's a good thing for her, because my daughter has problems with arm and leg coordination, side drum practice is helpful. I joined the band with some parents who have children like my daughter. We became volunteers and teachers in the band and developed the band further from a few teachers and students through family visits to encourage other parents to join us with their children.

At that time, my husband and I worked at my sister and brother's factory in Ningbo. We left my daughter with her grandparents. In addition to looking after her, Grandma also took her to the side drum band practice at the weekend (see Fig. 1). 
Fig. 1 Miss $\mathrm{H}$ practicing side drum

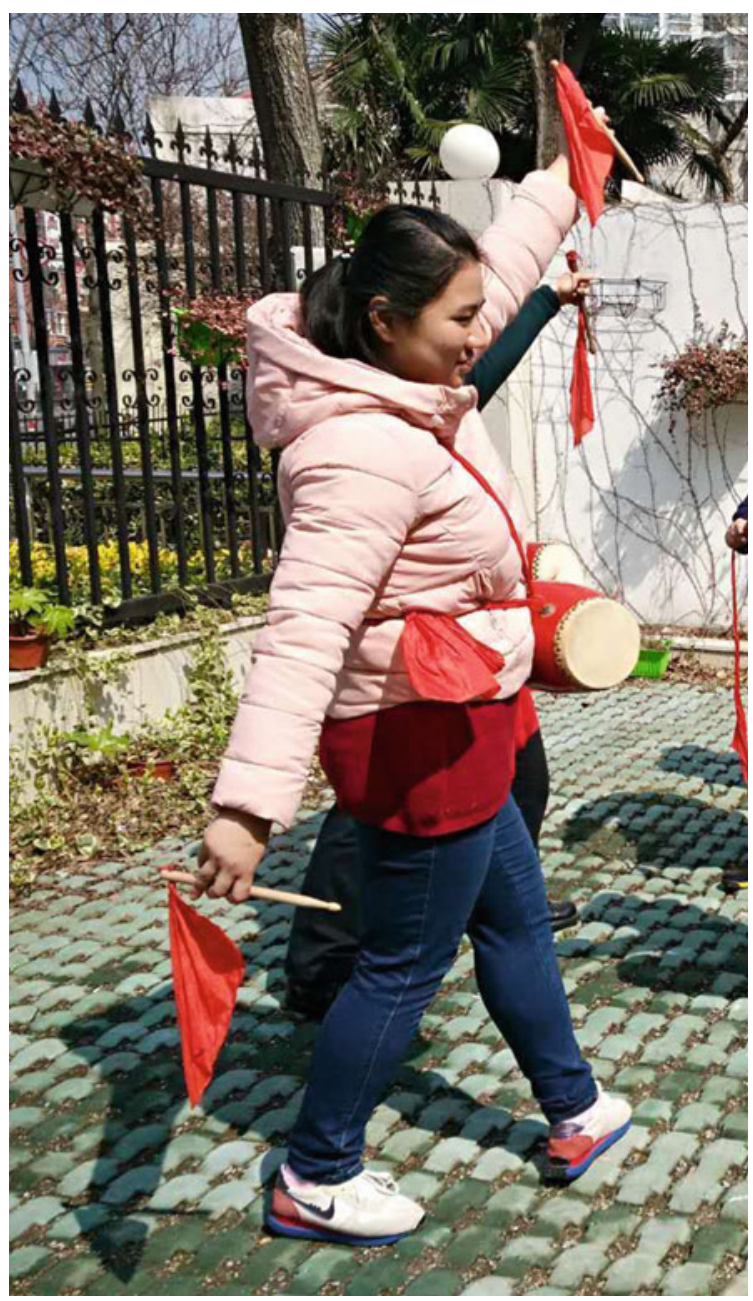

That same year, we quit our jobs in Ningbo and came back to Shanghai; the reason we took this job was for my daughter, it wasn't our intention that she should live a miserable life. So we moved back to Shanghai and spent more time with her.

Then I started to go to drum band practice at weekends, anyway I was free during the weekend. So we went to the practice and back home together. I started to learn the dance first and then taught my daughter and the other children afterwards. Even now, we still dance and practice together; the parents are also volunteers and teachers. We also formed another team called the Flat Drum Band. The difference between the flat drum and the side drum is the former is on a stand; the latter is tied to the waist.

Our band just performed at a sponsor's annual corporation meeting. An old gentleman asked the company to support us and that's why we were invited to their show. Our team played Chinese Kung Fu, one of our own choreographed dances. Usually 
we, the volunteer/teachers, learn the movements and actions from other players who practice in the park and teach our children afterwards. Now we have ten teachers and all of us have one thing in common, an unusual child.

Q: So, none of the teachers in your team played the drum before, right?

H's mother: Nobody touched the drum before; everything was new to us.

Q: What do you think H's behavior is like these days?

H's mother: She's doing fine, but she could do better if she worked harder. For most unresponsive children, rhythm is very difficult. It takes them several months to learn one thing which only take ordinary students a day. The problem is they can't remember movements and rhythm, they learn one thing today but forget it the next. $\mathrm{H}$ didn't know anything about drumming, and started studying simple actions with a "one, two, three" routine. We usually repeat one movement again and again until they remember.

H's father: It's very hard work teaching these children; sometimes they have to repeat one action many times.

H's mother: From 2005 to today, they have studied the drum for over 10 years, but quite a lot of students still can't play standard patterns. These students started playing the simplest "nine points" rhythm, and learned more complex actions later. That's how we learned Chinese Kung Fu.

This has been my life, accompanying my daughter for over 10 years. The group exercise helps children to develop themselves. My daughter has changed a lot, she used to be quiet and didn't like to talk, but now she's happy and a chatterbox. What a great thing.

But if the parents aren't determined, the children won't have any chance. There was an autistic child in our group for a while who I met during a family visit and I told his parents that keeping the child at home wasn't good for him. The parents changed their mind and joined us for a short while, but the mother gave up after she came to our group exercises several times, because she said it was too much for her. Actually, every parent in the group is doing the same thing, this mother was retired, but I was working. For her, it might be easier to keep her son at home, but he suffers when he loses his self-control. Compared to intellectually disabled children, an autistic child lives in his own world and doesn't care about other people's feeling at all.

Q: How was your experience playing the drum with $\mathrm{H}$ ?

H's mother: It was very hard, but now, after I'm used to this lifestyle, it's difficult to explain how difficult it is. It has become a part of my life now; I feel weird if I don't go there at the weekend. It's probably the same for my daughter; people get used to getting up late on cold days, or like to stay at home on rainy days, but she won't do that, she always insists on going to the group classes.

H's father: My daughter might be late for the exercises, but she has never missed once.

Q: Why?

H's father: Because she likes to spend time with her friends and play together. Home life is boring, because she can only chat with her parents or play on the computer.

H's mother: I think she's used to going there. 
Q: Does she like the group atmosphere?

H's mother: She looks very relaxed there and she's comfortable chatting with the boys.

H's father: Everybody in the group is the same, she doesn't worry too much, and feels can say whatever she wants to say.

Q: Does Dad go to the weekend practice with $\mathrm{H}$ ?

H's father: No, very rarely, my wife looks after this. I was a taxi driver and always too busy to look after her. Now I'm home but I have health problems after I had surgery several years ago.

Q: Do you encourage her to play the drum?

H's father: Yes, of course. When I had shifts, every other day, as a taxi driver, I took her to the center on my free day.

Q: Did you watch her perform?

H's father: Yes, when she was at school, we went to the practice together sometimes.

Q: Do you think the drum practice has changed her?

H's father: I think she's very happy being with people like herself where there are never any discouraging words, she feels happy.

H's mother: Sometimes she gets nervous and sweaty hands before she learns new movements.

H's father: Even her teachers know what she's like; they tell us: "Your daughter is very timid; she'll lower her head and stop talking to us if we say any harsh words to her." My daughter still lacks self-confidence, she always worries if she'll say something wrong before she talks. She doesn't feel confident in herself.

\section{Learning While Working Helps Her to Relax}

H's mother: H joined the Quyang Sunshine Workshop after she left the school in 2006. The basic work she does there is handicrafts; making red envelopes and sponge cup brushes.

H's father: They also make toothpicks sometimes, it's a kind of set of toothpicks for restaurants, two in one bag. It's very simple, a typical example of their work. The red envelope is for Spring Festival. They're paid for the work, but only a bit of money, probably several dozen yuan every month.

H's mother: The teachers at the Sunshine Workshop find this kind of work for the children through their social contacts.

Q: Do they work every day?

H's mother: Yes, they always have something to do every day.

H's father: When they don't need to work, they have handwriting or other classes.

H's mother: When they're free, the teacher teaches them to dance.

Q: Does H go to work every Monday to Friday?

H's mother: Basically, yes, but she might take a day off if she needs to go somewhere for a sports competition or social event. 
Q: Do you still walk $\mathrm{H}$ to work every day?

H's mother: No, not anymore, because her workplace isn't far away. I asked her if she needed me to take her to work with her, she said: "No, that would be very embarrassing if you take me to work at my age." So she usually goes to work and comes back home on her own, even in bad weather, because she always has her umbrella, she uses it for sunny days and rainy days.

Q: When does she usually leave home in the morning?

H's father: She usually leaves around 8 a.m. even though they don't have regular working hours. People only need to make a phone call in the morning if they can't go to work that day. My daughter usually leaves home between 8.10 and 8.15 a.m., and arrives at the workplace at 8.30 a.m. She finishes around 3 p.m. and gets back home before half past three.

H's mother: Actually, they do have a working schedule that requires them to arrive before half past eight, but getting there late isn't a big deal for the workers if they can explain the reason to the teachers. It's not a formal job, but they need to report to the teacher if they have to take a day off, because the teacher has to know the number of workers before she orders lunch.

H's father: Sometimes the workers have to leave $10 \mathrm{~min}$ late because they have to clean the workplace.

H's mother: The children have to clean up the place?

H's father: Yes, they do it in turn, so she will leave late once a week. Except for that day, she always gets home punctually, around half past three.

H's mother: She has to practice the harmonica with her friend's band after working on Tuesday, and she practices dance for half an hour on Friday afternoon. Apart from these days, she comes home early.

H's father: Sometimes they have to cancel the practice if the teacher can't make it.

Q: Do they let parents know if the practice has been cancelled?

H's mother: No, sometimes H arrives home early if the harmonica teacher can't make it.

H's father: Their teachers are volunteers who don't work at the workshop.

H's mother: The harmonica teacher is from the Youth Center in Hongkou District, he set up this band with piano, saxophone, and harmonica.

Q: Have you seen their performance?

H's mother: Yes, I saw their show. They perform regularly at the Youth Center.

Q: Do you know what songs she plays?

H's mother: Well, I don't know very much about that, because $\mathrm{H}$ told me she doesn't know what songs they play either.

Q: Do you like her playing the harmonica?

H's mother: Yes, of course. But we don't know anything about the harmonica so we can't help her, she has to learn herself. She practices at home sometimes, but she's too shy to practice in front of us, she always stops playing when I open her door. 
H's father: Playing the harmonica is part of her life and she likes to learn. As parents we have to support her. She got the harmonica from the teacher; we didn't need to spend anything and so there's no reason to stop her.

Q: Do you worry about H's work at the Sunshine Workshop?

H's father: There's nothing to worry about, we go to the workplace regularly for parent's meetings - we have to go there tomorrow evening again-and $\mathrm{H}$ tells us everything about what happens, what she eats, and what she does and all sorts of things. So, we don't need to worry about her.

H's mother: There is an annual parent's meeting to regularly update us about news and the children. The Sunshine Workshop belongs to the Disabled Persons' Federation (DPF) of Hongkou District; it's a proper company with a good reputation. The teachers are nice and caring people, they usually set up some activities after the children have finished their work.

H's father: Compared to other similar workplaces, the Quyang Sunshine Workshop is a pretty good one. Previous national leaders have visited the place, from Xiaoping Deng, Jiang Zemin to Hu Jintao, but Xi Jinping hasn't been yet.

H's mother: I remember Hu Jintao came in 2007 for Special Olympics.

H's father: The leader's visits are very special and proud events for the workshop, so they have a picture wall of the events.

H's mother: The name of the workshop was written by Xiaoping Deng, and his successors came here to remember him. It's why this workshop has become so famous.

Q: Do you worry about the people who H gets to know through her work?

H's mother: I worry sometimes, I just don't like her to be pick up some bad behavior from the other children, so I have to point out any problems to her.

H's father: It's hard to avoid it in this environment, because these children all have their own problems.

H's mother: Once I saw her giggle loudly when she was alone, and I asked her: "What are you doing, did you pick up this bad habit from your friends?" I said that because she behaved normally before and never laughed like this, but in the workplace, those children have all kinds of different odd habits. $\mathrm{H}$ is really good at imitating this kind of bad behavior, much quicker than learning good things, but if we point it out she correct her mistakes immediately. I think she's really good at picking up bad habits, I don't mean bad things but bad manners.

My daughter is so excited about the party at the workplace this afternoon, she'll be performing two songs, and one is Firefly. She downloaded the songs to her phone and she'll sing along with the music later. To be honest, it's not an easy job, I suggested she only sing Firefly, but she won't listen to me.

Q: Does she like cultural and musical events?

H's mother: Yes, she likes to sing and dance everyday (she's laughing). The Sunshine Workshop is a pretty good and safe place. Also, H isn't a bad person and won't make a fuss. She calls me every afternoon before she leaves work and I always tell her to be careful when she's crossing the road. She always comes back home immediately and won't go anywhere else on her way back.

$\mathrm{Q}$ : Does $\mathrm{H}$ have any good friends at the workplace? 
H's mother: Most of my daughter's friends are children from the side drum band, because the parents get on very well and the children have become good friends. We usually go out for a meal or karaoke together.

$\mathrm{Q}$ : Did you have to think about letting $\mathrm{H}$ get a proper job?

H's mother: The Sunshine Workshop recommended her for a job once.

Q: Recommended employment?

H's mother: There is a "reemployment of the disabled project" through the district DPF office; usually they help mildly disabled people find a job. They can't stop the employers' bias against these children, they often get the most difficult and dirty work and usually won't get a contract after a 3-month probationary period.

H's father: People at the workplace usually look down on these children, they only keep our children for a 3-month probationary period. Some of my daughter's classmates don't like to take a second probationary period after they fail the first one, because it's a kind of torturous experience. My daughter is the same, she won't leave the Sunshine Workshop to find another job. Here the teachers treat her as an equal to their own children, some teachers' children are in the same situation. But in the world outside, it is totally the opposite.

H's mother: She's unsociable in the outside world, because she can't join in people's conversations at all. She was recommended for a job by the DPF office once, but she was lonely there, but at our weekend group, people feel at ease and carefree to chat with each other.

H's father: Yes, she went for a proper job once.

H's mother: It was a job at a bakery. I went to the interview with her at the Xinyu Bakery, at the Jiangwan Sunshine Workshop. After that, when the careers teacher at the DPF center asked my daughter about her work experience, she said: "I'd like to stay here because I'm not fit for the outside world." The teacher laughed and didn't put her forward for another job. My daughter is scared; one reason is the distance between home and the workplace. She didn't want me to go to work with her, and she wasn't sure she could cope with the journey by herself.

I guess she might feel better if she had a couple classmates to keep her company. I know this, because she worked with three other girls in the same area and she was very happy. They'd meet at the bus station at the Foreign Language College and go to work together on the No.875 bus.

H's father: Some other students at the workplace took the job, but quit later. One girl said the work was very hard and they had been given the most difficult work with the oven. They were also despised by other people. So the girl quit.

H's mother: This girl is more capable than our daughter, she and the other students went to work in the summer, and they worked in the hottest part of the bakery. She decided to leave and came back the Sunshine Workshop.

H's father: After all, there aren't that many loving people in our society. Hong Kong and Taiwan have more caring people than the mainland.

H's mother: In one training class, a teacher talked about a disabled person's life in Taiwan. They have some trained volunteers to accompany them when they go to work until they get used to the job, but Shanghai doesn't have this kind of social service yet. 
Q: Does H still need a place that makes her feel secure?

H's mother: Of course, she feels more relaxed in a safe place. At the Quyang Sunshine Workshop, she feels free to speak, because nobody will feel the need to correct her. Maybe it's just because the children don't really understand each other, so they just let mistakes go. Everybody is the same.

H's father: My wife is right, our daughter feels safe and relaxed at her workplace. The low pay doesn't matter, because she's happy. It's a place where she can say or do whatever she likes.

H's mother: I really wish we had a caring person to look after my daughter to help her adapt to society, step by step. That would be a really wonderful thing for her.

H's father: But it's unrealistic.

H's mother: It's just my wish.

Q: How would a volunteer help her be included into society?

H's mother: For me, the ideal situation would be for her to work in a normal place with a female worker as her mentor, to teach her about the workplace and walk home with her.

Q: So, would you want her to be part of society even if she isn't in a safe space?

H's mother: Yes, I hope she can become a part of society one day. You can't tell that she has a problem by looking at her, especially if you're a stranger. Sometimes when we walk home along West Dalian Road after drum practice, some young girls ask her for directions - what's the way to Hongkou Football Stadium or the Foreign Language College or something like that-because they can't see that she's different. She knows the right directions, but she doesn't dare answer them until I come to help. She has a chance to have a normal life. One time, when some people came over to our place, they thought my daughter was a volunteer.

Q: But why are you so determined that she joins in society when she's a little bit afraid of the outside world?

H's father: We want her go out into the world in a slow way with some help, little by little.

H's mother: Experiencing a real environment and its difficulties is the only way she can improve her social skills; her current workplace is safe, but it isn't helpful for her development. If she gets upset outside, we can work out the reason together and find a way to avoid it next time, that would be an improvement. She'll have to live alone when we're old and face all the problems on her own. Rather than just going out alone one day and being hurt by all the things she can't deal with, it would be better to let her face smaller problems, little by little, until she's strong enough to face something more serious in the future.

It's the way we grew up. Years ago, after I failed the high school entrance exam, I came to Shanghai to learn tailoring and went back to my hometown afterwards. I found a job at a clothing factory, then moved to Shanghai and worked for my relatives. After they closed the business, I found another sales job at a shopping mall. It wasn't easy, but I went through all of these changes and I want my daughter to grow up in the same way. I believe $\mathrm{H}$ can develop herself if she has a good, normal person as a guide. Our daughter isn't bad; she's independent, but poor at explaining herself and has no understanding of money. 
H's father: We wish she could engage with society, but we know it's very hard for her. It's too difficult to find a loving and caring person to help. Why do I say this? For example, in my family, I have four siblings - two big brothers, one big sister, and a little sister-their children are the same age as my daughter, more or less, but not one of them likes to talk to her. Even though they're blood relatives, they don't like her. If your own relatives are like this, and even they can't look after her, how can you depend on somebody else even if they have a very warm heart? We have thought this thing through and now we'll just get on with making sure she's a happy person, that's what matters for us.

\section{How Can She Be Independent Without Understanding the Value of Money?}

H's mother: H isn't fussy about food or clothes. If I ask her what she wants to eat, she always says whatever you're cooking. She has the same attitude to clothes; when we go shopping together, she is never picky about clothes or asks for branded stuff. She just lets me choose her clothes for the day. Of course, we don't buy her cheap stuff either, because shabby clothes would make her look poor. She wears the same things to her ordinary peers. These days, she has a salary and never uses it, but I don't mind spending money on her clothes, because as a one-child family parent, I care about her appearance.

Q: Are you close to your relatives?

H's mother: We very rarely see them, because everybody is busy at work.

H's father: I have a big extended family, three nephews and one niece, but all of them are busy with their own families. We're in contact through WeChat daily but only meet up once or twice a year.

H's mother: Usually we only meet at Spring Festival and Tomb-sweeping Day, and keep in touch by WeChat the rest of the time.

Q: Do they know about your daughter's condition?

H's mother: Yes, they've known for a long time, since $\mathrm{H}$ was at primary school and struggled with her studies.

H's father: At that time, we lived with my parents and saw our relatives more often when they came to see them. After my parents passed away, we didn't see each other as often as before.

H's mother: People have to concentrate on their own family, all of our siblings are parents and grandparents already. If our daughter was different, an ordinary young woman of 28 , we might have become grandparents as well, but we won't have that experience now.

Q: Does $\mathrm{H}$ have an effect on your relationship as a couple?

H's mother: No, not at all. It's the way it is, so as a family we have to share the responsibility. Our parents suggested that we should have another child, and I could have had a second child, but I chose not to. Because most parents always have a 
favorite child - the clever or healthy one-I can't say that I'd be any different. If we had another child, H's situation could have been worse and she'd be more vulnerable. It would not have been fair to $\mathrm{H}$ at all. So, the best thing was to only have one child in the family and give her all our attention.

Q: How about your circle of friends?

H's mother: My social life has always centered around my daughter. Except for our relatives, I've never mentioned my daughter to other friends, because I have to be careful about how they would react. I don't go to ordinary people's events if I can help it, but I go out with other families in our group quite often, because we have one thing in common, our children connect us.

Q: How about Dad?

H's mother: My husband has some ordinary friends too, but he doesn't go out with them very often either. Sometimes these friends ask about our daughter's age and say they know some good boys to introduce to her, but my husband can only say: "Thanks, but she has a boyfriend already." This hurts him deeply inside, but we can't do anything about it.

Q: Is $\mathrm{H}$ independent?

H's mother: She isn't bad with everyday life skills. She's okay with cooking, boiling hot water, and using the microwave to heat up food and so on. She can also make a vegetable salad in hot weather. Sometimes, she helps me with the washing as well; she doesn't have a problem with the automatic washing machine. Once, she was left at home alone when my husband went to hospital. We weren't sure if she could look after herself and called my mother who lived in Ningbo to come to our place and look after her. When she arrived, my daughter had cooked a meal and boiled water for her.

Q: When did you start teaching her life skills?

H's mother: When she was at primary school; in her first year she started washing her school uniform and red scarf. I helped her to hang up the washing afterwards; I didn't mind washing the stuff again if she hadn't done a proper job. I thought, she isn't a smart girl, but she has to grow up to be an independent person. I taught her these life skills step by step. Before she learned to use the vacuum flask, I let her fill up the bottle with cold water just in case she got burned by the hot water, until she got used to doing it.

Q: Can she cook?

H's mother: She can cook some simple meals like making rice using the rice cooker.

H's father: The most worrying thing for us, is she doesn't know how to use money, and how can she live on her own without knowing the value of money? In this world, we have to buy everything, oil, rice, and other things with money every day. If you can't deal with money, it's problematic. We keep teaching her to use the ATM at the bank-inserting the card, typing in the password - but she always forgets how to do it the following day.

H's mother: I usually take her with me if I need go to the bank and keep an eye on her to remember the password, or write out a form and deal with the account business by herself. My daughter is a timid girl and she isn't good at coping with 
communication issues either. Sometimes she's even scared of people who ask her for directions on the street. So just in case she's cheated by someone on the street, I have to remind her that she mustn't talk to strangers when she goes out. With her condition, some terrible things could happen to her if she isn't very careful. Especially as she's a girl. Some girls like her have been abducted by bad people and were pregnant by the time the police found them.

Q: Do you teach her anything else except for life skills, how to use the bank and not talking to strangers?

H's father: Actually, we teach her everything we know or everything we can.

H's mother: We also taught her to respect the neighbors and how to address them depending on their age and her relationship to them; how to reply to other people and have a conversation or something like that. If I can, I usually take her with me to do most things, like going to the food market together at the weekend. I usually let her hold the money and pay for things, but with my help.

H's father: Her problem is she doesn't have a sense of numbers; for example, she can't work out how much change she should get.

Q: Can she use Alipay? ${ }^{1}$

H's father: No, she can't.

H's mother: Because we don't have an Alipay account yet, I guess if we do, my daughter will learn how to use it.

H's father: We don't know anything about Alipay or the Internet or computers, we didn't learn this kind of thing at school.

H's mother: I applied for one account with the help of my nephew, but I didn't dare use my bankcard with it. I use the same password for several cards, if anything should happen to the password, I couldn't bear the consequences. I've been told if I apply for a new bank card and use a different password that will be fine, but for some reason the application didn't go through and I abandoned the plan. Anyway, at my age it's too difficult to remember too many passwords. To be honest, I know I should learn more new things to make sure I don't become disconnected from modern society.

H's father: Alipay is very convenient and you only need to scan the barcode to pay a bill when you go shopping.

H's mother: Didi Taxi ${ }^{2}$ and bike-sharing are convenient new things as well, they make life much easier, but we're behind the times now.

H's father: We can't use them.

H's mother: What can we do? If our daughter was an ordinary child, she'd be able to help us learn these new technologies, but we're completely the opposite to normal families. Without Alipay, we have to use cash for delivery services and pay an extra fee if we want to shop online.

$\mathrm{Q}:$ So, $\mathrm{H}$ is able to take care of herself, but still needs a helper?

H's father: That's right, her main problem is with using money.

\footnotetext{
${ }^{1}$ Alipay is the Chinese counterpart of PayPal. As well as using it for online payment, people also can use it to pay bills in many shops and restaurants.

${ }^{2}$ Didi Taxi is a Chinese equivalent of Uber.
} 
H's mother: Another problem is she's been protected by us for too long. These children don't know how to follow the weather reports to change their clothes or bedding yet. Sometimes they won't know how to take off the duvet when the weather gets warmer without their parents reminding them. These days, if my daughter asks me what she should wear, I usually ask her to think about the weather first and tell her that she should choose the right clothes for the weather, rather than for taste. Wearing a T-shirt in winter or the other way around wouldn't be a clever thing to do, but it takes time to learn, right?

Q: Has $\mathrm{H}$ had a relationship yet?

H's mother: No, she doesn't have a boyfriend. I don't think she understands what the meaning of a boyfriend or relationship is yet, because she usually stays with her own people and doesn't have any real idea about what this means in her life.

Q: What do you think about her getting married?

H's mother: We discussed this issue and we think she'd be better off with a family, but if she has to marry to an intellectually disabled person, I think she'd be better off single. A light, physically disabled man, but with a normal mind would probably be an ideal choice if the guy is truly in love with her. Even though we worry that this type of man might only treat her well before my husband and I die; after that, he might send our daughter to a nursing home and sell our property and run away with the money. If this happened to her we'd never know or be able to help.

There are some intellectually disabled children who got married and some of them have children already. I met some of the parents of these families from Yangpu District and Baoshan District during a meeting. Usually they like to choose a nonShanghainese, but someone who works in Shanghai and comes from a poor family to marry their child, and they can help raise the baby if they have one. Things look pretty good for them at the moment, but who knows what will happen to these families in the future?

If we chose a man with the same condition for our daughter-a normal person but very poor-after we die and leave a property worth several million yuan to them... The man might abuse her or treat her very badly. Just thinking about this makes me very upset. We can't reconcile this and we feel a deep inner conflict (she's sobbing with grief).

She doesn't want to have a family right now, but who knows if she'll change her mind. One day, it could be an issue when she wants to get married or she reaches biological maturity. There's a girl who lives on Jiangwan Street, she insisted on getting married when she was in her thirties. Her mother had no choice and found a man for her. Their child was an intellectually disabled baby. That's a huge conflict, right? (crying).

For $\mathrm{H}$, having a family is unlikely, but if the opportunity really comes one day, I'll fight for her and be very careful about the man. My daughter doesn't have any physical problems, but also, she doesn't have any desire yet. After all of her cousins were married, I asked her if she wanted to have a family of her own, but she said no. At some special occasions, like her cousin's wedding, she said: "I'd like to be a bride one day." She doesn't really understand the meaning of marriage.

Q: What's your plan for H's future? 
H's mother: The future? We never stop worrying about her, especially knowing there will be a time when we might be too old to look after her (sobbing). She's independent enough, but she can't deal with money, that's her most serious problem. I can't stay calm whenever we talk about my daughter's future.

My concern led me to volunteer to work with intellectually disabled children, joining group events and meetings at the district DPF center. Later, I was elected as the chairwoman of the District Association of Persons with Intellectual Disability and their Relatives, to represent their thinking, gather complaints and suggestions, and make proposals to the Shanghai association.

Generally speaking, these children don't have financial problems when they get old, but they need looking after because after their parents pass away, they can't depend on their cousins; they will have their own family to look after. It's our biggest problem and we worry about the future.

H's father: We've thought about this issue very carefully. When we can't look after her anymore, the whole family will move into a nursing home together. It's not just our decision but also one agreed by other volunteers/teachers in our group.

H's mother: Right now, we don't want to make such big deal (crying seriously). At least we can go to a nursing home together - a family style nursing home-live there together. My daughter doesn't like the idea and insists she won't go to the nursing home with us; she promises that she'll take care of us when we're very old. She said: "It's my decision, I won't go to a nursing home and wait to die there."

She has a very bad feeling about the nursing home, because she knows her grandma went there when she was very sick. That's why she believes a nursing home is a place where old people go to die, and said she won't go there whatever happens (choking on her tears). Even though she wants to live at home with us when we're old, she won't be able to look after us, because she has problems with shopping and can't even buy vegetables, we might all die of starvation. She doesn't see it this way, so, unless we find a better solution, the nursing home is our best choice. It's the same for other families in our group. The ideal thing for a family like us is that the parents stay healthy and die after the child. That would be a real relief for the parents (starts to cry again). It's a common problem for all families like us, even some famous people are the same, Yi Qin - the famous actress- has an intellectually disabled boy.

H's father: Director Jin Xie's son is also the same.

H's mother: Actor Xu Huang has an intellectually disabled son as well. Yi Qin still had to bathe her son when she was very old, sometimes she was beaten by her son when he was angry. This man died quite early, in his fifties.

H's father: It's true.

H's mother: Actually, if we're healthy and live long enough, I would rather our daughter died before us, but right now, nobody can tell the future and we can only wait and see what happens.

H's father: We have to look after ourselves and make sure we live longer to be with her.

H's mother: In my mind, the greatest thing the government could do for us is to set up a special nursing home for intellectually disabled people, then the parents wouldn't need to worry that their children would be bullied by other people there. 
Q: What would be the purpose of a special nursing home?

H's mother: Compared to people with physical disabilities, our children are more naive.

H's father: Those people might have problems with their hands or feet.

H's mother: But they can be clever and selfish. Intellectually disabled children make up the most marginalized group of all disabled people; they are the most vulnerable in the community. A developed mind is the difference, other disabled people are able to use money or ask other people to buy things for them, but our children don't understand the value of money.

$\mathrm{Q}$ : So, the basic worry is about other people being unkind and taking advantage of them?

H's mother: Yes, that's right.

Q: Does Mom worry about discrimination?

H's father: Discrimination is everywhere, but these days their situation is much better.

H's mother: They've been treated more fairly since the Shanghai Special Olympics. Before that time, discrimination was a very common thing, we even had to deal with bias from our own relatives.

Q: Does $\mathrm{H}$ feel discriminated against?

H's mother: She never talks to her female cousins, because she worries she might say something wrong. Usually after the family Spring Festival dinner, the children like go to a karaoke hall, but her cousins never invite my daughter. This makes us very upset (she's choking with sobs). My daughter won't socialize with them, but at least they could invite her. My daughter usually tries to reassure us: "It doesn't matter, because I know you won't feel relaxed if I go out with them.” (crying).

I have to say, the volunteers we met at the events are much nicer than our relatives. At least the volunteers, some of them are college students like you, are willing to talk to our children, but her cousins won't treat her the same way. Our relatives treat us less kindly than outsiders.

Q: Acceptance by other people is very important for $\mathrm{H}$.

H's mother: Definitely. The last time we took our children on a trip, some selffunded volunteers went with us and they were very nice to the children. What a lovely thing!

It breaks my heart when I talk about these things. I'm all right if I don't think about it, because this problem always upsets me... my heart has been broken too many times since we had her.

H's father: Compared to other people, our fate is so difficult.

H's mother: Sometimes we have to force ourselves to think about something nice; for example, if our daughter had no disability, she might have left home already and wouldn't be able to look after us if we became ill. It's a common story with parents who have a grown-up child, their children are always too busy to take care of aging parents, but if we don't feel well our daughter can make a cup of tea for us.

Under their parents' wing, these children can enjoy a carefree life; they also receive medical care and around 2,000 yuan as allowance or salary. It's pretty good, they can afford a basic lifestyle. The only problem we're concerned about is who 
will care for them in their old age after their parents die. For our daughter, the main problem is about her inability to use money properly.

H's father: We mean if she doesn't know how to withdraw money and spend it, she can't live independently.

H's mother: Firstly, she has to develop a proper sense of value and use her monthly allowance in a sensible way; secondly, she has to be careful with change when she uses cash. There are bad people who might cheat herby giving the wrong change.

H's mother: $\mathrm{H}$ usually goes to the local store near her workplace, sometimes she gets the same change no matter if she pays with a 10 or 20 yuan note for the same thing, but she doesn't see that there's something wrong with that.

H's father: She can't live on her own without understanding the value of money.

Q: Do you worry about anything else?

H's father: Hospital is another thing, she's fit and healthy at the moment and hasn't had much experience with hospitals, but one day, when she needs to see a doctor, she might not be able to communicate her problems very well.

Q: So, basically, you worry about her seeing a doctor and her sense of money, right?

H's father: The money issue is the most important, because it is something she needs to understand for everyday living.

\section{Interview with Ms. H's Teacher}

Interviewee: Teacher Han

Interviewer and writer: Shuwen Wang

Interview date: January 3, 2017

Interview place: Office of Quyang Sunshine Workshop in Hongkou District, Shanghai

Q: Could you tell me the difference between the Sunshine Factory and the Sunshine Workshop?

Teacher: They're the same thing, the Sunshine Factory changed its name from "factory" to "workshop."

Q: What about the Sunshine Home?

Teacher: They have different objectives. The Sunshine Home focuses on study, learning, and entertainment; the Sunshine Workshop is about developing labor and labor skill training, basically.

Q: Do these two institutes share the same space?

Teacher: Yes, we're based in the same place.

Q: There is a mixture of work, study, and entertainment?

Teacher: That's right, the students at the Sunshine Home have lessons in the classroom and the workers at the Sunshine Workshop make products for outside clients.

Q: Which institute do you work for? 
Teacher: I teach at the Sunshine Workshop and I'm responsible for production and work skills training.

Q: I saw the workers making red envelopes for Decathlon today.

Teacher: Decathlon is a clothing company, so I'm not sure about that, but we work with a printing house that has a contract with Decathlon. They print the envelopes and let us complete the process which is folding them.

Q: You have a working arrangement with a printing house?

Teacher: Yes, that's right.

Q: Do you get other jobs from them apart from making red envelopes?

Teacher: Yes, we get some different jobs, like threading a string on a label or adding double-sided tape to the back of a normal envelope or something like this.

Q: How do you choose the right jobs?

Teacher: It depends on several factors, basically we can't accept jobs that are too complex, or with a short turnaround or where the price is too low.

Q: Why do you have to give urgent jobs away?

Teacher: Usually the jobs from the printing house are huge quantities and our workers are much slower than normal workers. We wouldn't want to miss a deadline so it is better not to take the work in the first place.

Q: Except for the working speed, do they have other differences from normal workers?

Teacher: They're very different groups. For an ordinary worker, it's natural to correct errors and improve work efficiency when they become used to the process, but our workers can't think in the same way, so even our best worker can't compare to the average normal workers.

Q: You mean they can't think about ways to improve their work efficiency on their own?

Teacher: Very few of them are able to think about how they could work quicker or better.

Q: Did they receive some skills training before they join your workplace?

Teacher: We do have a pre-work training program, but few people can do a proper job after that, so we have to give some of them special instruction afterwards. It's a slow process.

Q: Do you have some teachers to train them?

Teacher: Of course, all four of our teachers can undertake training work.

Q: Take making red envelopes for instance, how long does it take you to teach them to fold the envelopes and put them in a bag?

Teacher: It doesn't take that long to teach them this job, even though they learn at a different pace; except for a few workers, most of them can learn this. For example, we can tell them how to fold and seal the different sections together many times, but some of them have to work in their own individual way to fold the envelopes. Working in this way they are never going to be efficient. They just fold up the envelopes one by one.

Q: Do you have any basic requirements for their work? 
Teacher: Our basic requirements include trying their best to avoid damage, don't waste material, and following a quality guide if they can. For them, the last requirement isn't a very strict or precise rule. Sometimes a worker who fails the training has to be kept away from certain jobs. For example, we only have 13 workers that can work with double-sided tape. Usually, these children have shaky hands and this prevents them from doing precision work.

Q: So, not everybody at the workplace can do all the jobs?

Teacher: No, H can't work with double-sided tape. We have around 30 workers at the workshop; sometimes the students of the Sunshine Home come to help if we have too many jobs. The ideal situation would be half the workers doing the double-sided tape job, but the fact is that only 13 people can do this, even though most of the people here are mildly disabled. It's hard to tell, because their practical ability can depend on their intellectual condition; some people at the Sunshine Home are quite good at complex work.

$\mathrm{Q}$ : Is there a particular standard you need to achieve?

Teacher: The work is based on productivity, so we use as many as workers as necessary to finish one job at a time.

Q: Does the printing house pay you the same as the ordinary labor market?

Teacher: Our place is a commercial concern as well and we can't afford to take low-paid work, but sometimes some factories will cancel a contract because our price is too high-the workers are slow, but they are not cheap.

Q: How do you calculate their salary?

Teacher: We follow a piece-rate wage system; their workload and their income depend on how much they can produce.

Q: How do you distribute the salary, by card or cash?

Teacher: We pay cash.

Q: Do you provide lunch as well?

Teacher: Yes, but they pay a fee of 60 yuan per month.

Q: It's a pretty fair price. Do they also have a lunch allowance?

Teacher: That's right, we only can afford to supply lunch with their allowance from the Quyang Subdistrict office. We order meals from the Citizens Inn, a community service center. They also have a meal delivery service.

Q: What time do they finish?

Teacher: Normally they work from around 10 a.m. to 3 p.m.

Q: How often do they get jobs?

Teacher: Hard to tell, but we're quite busy at the moment. But our off-season will come soon, and our workers will have more free time.

$\mathrm{Q}$ : What do they do in their free time?

Teacher: We have a teaching schedule which includes classes in dancing, singing, and other things.

Q: Except for the salary from their work, do they receive any other income?

Teacher: That depends on their condition. Students from the Sunshine Home are usually severely disabled and unable to work, so they receive a monthly allowance of over 1,000 yuan from the subdistrict office. The students who work at the Sunshine Workshop have milder conditions and are able to work, so the government offers 
them three kinds of social insurance and funds and also an allowance of 876 yuan and a lunch allowance.

Q: There are two different groups of people from to the Sunshine Home and Sunshine Workshop?

Teacher: Yeah, there are two groups, those with mild condition who work for the Sunshine Workshop, but students with a moderate or severe condition belong to the Sunshine Home. Generally speaking, our workers have to pass a simple working skills training program to become low-skilled workers. The most agile workers also have a potential opportunity to be recommended for a proper job. We have some pictures of students in real jobs on our office wall, quite a few.

Q: Do you have fixed contracts with some companies? What kind of jobs do you usually get?

Teacher: No, we don't have fixed contracts with anyone, but quite a few companies come to the DPF office to hire a couple of workers. They are usually hotels or similar companies.

Q: Generally speaking, what kind of jobs?

Teacher: Basic hotel jobs like room service, collecting used bedding and towels for the room laundry, or working in storage in the kitchen. To be honest, the students from our workshop can't compete with piece-work workers from outside; if a worker's average production is more than 100 boxes, our students could probably only finish 20 or 30 in the same time.

Q: Can they become affiliated to a company?

Teacher: Of course, they can. Some of our students are affiliated workers and earn the minimum salary of 2,190 yuan a month.

Q: Could you explain more about this affiliated worker policy?

Teacher: Shanghai's employment policy allows a local company to set up $3 \%$ of jobs for disabled people and this mean that 3 out of every 100 jobs must go to disabled workers. However, because of work efficiency, these companies tend to pay the salary and social insurances but allow the disabled workers to stay away. Special workers in the workplace might cost them more money and effort, so paying them not to be there is best for both sides.

Q: How is H's performance here?

Teacher: She's pretty good. She is an enthusiastic worker and highly adaptable socially.

Q: Does she like to chat with her colleagues?

Teacher: Of course.

Q: Does she like to communicate with her teachers?

Teacher: Not really, she seems to be afraid of the teachers, but gets on very well with her classmates.

\section{Interview with Miss H's Co-Worker}

Interviewee: Mr. Lu 
Interviewer and writer: Shuwen Wang

Interview date: January 3, 2017

Interview place: Office of Quyang Sunshine Workshop in Hongkou District, Shanghai

Q: Do you know H?

Mr. Lu: Yes, we studied at the same school, the Miyun Road Special Education School.

Q: Do you remember what she liked at school?

Mr. Lu: She had short hair, shorter than now, she was active and open and liked sports, skipping, and other things.

Q: Did she have a good relationship with the teachers and other students?

$\mathrm{Mr}$. Lu: She was quite close to our classmates, chatted with us quite often. She had a pretty good relationship with our teachers and liked to talk to them.

Q: How was her performance at school?

Mr. Lu: She studied very hard and always finished her homework on time. She loved domestic science and joined in the school's general cleaning sometimes.

Q: What happened afterwards?

Mr. Lu: She graduated before me and joined the side drum band. I graduated in 2009 and went on to the baking training program, but we met up again in the side drum band and the Sunshine Workshop in 2014.

Q: Had she changed when you met her again in 2014 ?

Mr. Lu: Definitely, she wasn't good at music before, but now she can play harmonica. And she's become more open.

Q: What are H's good points?

Mr. Lu: She's willing to help other people, she helps me with work as well. Sometimes she reminds me to wear extra clothes so as not to catch a cold.

Q: How about her bad points?

Mr. Lu: Her bad points are she likes to chip into other people's conversations (he's smiling), sometimes she might lose her temper.

Q: Did you ever see her get angry?

Mr. Lu: Hum, she might get angry if somebody criticizes her harmonica playing.

Q: What does she do when she's angry? Does she argue with people?

Mr. Lu: No, she doesn't argue, she never gets angry with other people, just gets upset and cries by herself.

Q: Does $\mathrm{H}$ have hobbies?

Mr. Lu: She likes dancing, she's good at Grateful Heart and Little Apple. She plays the flat drum and side drum. Chinese Kung $F u$ is her favorite.

$\mathrm{Q}:$ Are you close to each other?

Mr. Lu: Yes, we talk with each other quite often. We usually chat about music, news and watch her favorite cooking program together, Popular Food. We talk about the programs and the nice food as well.

Q: Do you talk about music and play musical instruments together?

Mr. Lu: Yes, I play harmonica and clarinet, so I became her harmonica teacher and help her practice.

$\mathrm{Q}$ : Is she a quick learner? 
Mr. Lu: She's very good, we usually practice harmonica together every Tuesday at the Sunshine Home.

Q: Is she a good harmonica player?

Mr. Lu: She isn't bad. She can play, Let the World Filled with Love ${ }^{3}$ and You Raise Me Up.

$\mathrm{Q}$ : Is she close to the other colleagues?

Mr. Lu: No, she doesn't communicate with other people as much as she did at school.

Q: Why?

Mr. Lu: I don't know.

Q: Does $\mathrm{H}$ have any other friends apart from you?

Mr. Lu: Yes, this guy and other guys all are her friends (he points at some colleagues around the office), six friends altogether.

Q: Do you hang out together?

Mr. Lu: We go to Carrefour or have a wander on the way back home sometimes.

Q: Has she impressed you in any way?

Mr. Lu: Yes, she supports me as team leader and flag carrier?

\section{Interview with Miss $\mathbf{H}$}

\section{Interviewee: $\mathrm{H}$}

Interviewer and writer: Shuwen Wang

Interview date: January 3, 2017

Interview places: Office of Quyang Sunshine Workshop in Hongkou District, Shanghai

Q: What did you have for breakfast?

$\mathrm{H}$ (smiles): Cake, I had cake.

Q: What time did you leave home this morning?

H: 8.30 a.m.

Q: Did you come alone?

$\mathrm{H}$ : Yes, I came here by myself.

Q: What do you do here?

$\mathrm{H}$ : Make red envelopes.

Q: Do you also make rubber erasers?

H: Erm...

Q: Which work do you prefer?

$\mathrm{H}$ : I like making red envelopes.

$\mathrm{Q}$ : Why do you prefer making red envelopes?

(H doesn't answer but laughs.)

Q: Do you prefer to stay at home or come to work?

\footnotetext{
${ }^{3}$ Let the World Filled with Love refers to a very famous Chinese charity single, which became popular in 1986 when it was performed by over 100 singers.
} 

H: Here.
Q: But why?
$\mathrm{H}$ : Because here I have lots of friends to play with.
$\mathrm{Q}$ : Who are your closest friends?
H: Xiao L, Xiao Z, and Xiao H.
$\mathrm{Q}$ : What do you usually talk about together?
H: Just small talk.
Q: Where is the food more delicious, home or the workplace?
$\mathrm{H}$ : The food here.
H: What hobbies do you have?
$\mathrm{H}$ : Singing and dancing.

\section{Observation of Miss $\mathrm{H}$ in the Drum Team}

Observation date: 9:00-11:30, November 27, 2016

Observation place: Cultural and Sport Center of Hongkou District DPF, Shanghai Observer and writer: Shuwen Wang

\begin{tabular}{l|l|l}
\hline Time & Content & Observed activities \\
\hline 9:00-9:13 & $\begin{array}{l}\text { All of the students practice on the } \\
\text { second floor. H's mother and other } \\
\text { volunteers stand at the front to teach } \\
\text { them }\end{array}$ & $\begin{array}{l}\text { H is pretty good at the dance, from } \\
\text { time to time she takes a look at the } \\
\text { floor or someone else. When they are } \\
\text { changing the formation from one team } \\
\text { to two teams, H seems to forget her } \\
\text { movements and place, so she watches } \\
\text { both sides and walks to her place } \\
\text { quickly. At the end, H forgets a half } \\
\text { squat movement, but she follows the } \\
\text { other students }\end{array}$ \\
\hline 9:13-9:18 & $\begin{array}{l}\text { The second round of side drum } \\
\text { practice }\end{array}$ & $\begin{array}{l}\text { H doesn't forget her actions, but she } \\
\text { turns around and watches the others } \\
\text { all the time. H watches carefully and } \\
\text { laughs sometimes when the teacher } \\
\text { gives somebody individual } \\
\text { instructions. She covers her mouth and } \\
\text { laughs at a student who has a runny } \\
\text { nose and gets a tissue from H's mom }\end{array}$ \\
& Break time & $\begin{array}{l}\text { H sits down and chats with her } \\
\text { teammates while she uses her hand as } \\
\text { a fan. Later, she stands up and chats } \\
\text { with a tall boy. H gives the observer } \\
\text { some hot water after H's mom } \\
\text { reminds her }\end{array}$ \\
\hline 9:18-9:24 & &
\end{tabular}


(continued)

\begin{tabular}{|c|c|c|}
\hline Time & Content & Observed activities \\
\hline $9: 24-9: 34$ & $\begin{array}{l}\text { During the group dancing, almost half } \\
\text { the students have problems with } \\
\text { movements or rhythm. The teachers } \\
\text { give individual instruction to the } \\
\text { students and help them catch up with } \\
\text { the formation }\end{array}$ & $\begin{array}{l}\mathrm{H} \text { takes off her coat when she feels hot } \\
\text { and only wears her red sweater. } \\
\text { Practicing the group dance, Moonlight } \\
\text { over the Lotus Pond and Bright } \\
\text { Spring Day. H's movements are } \\
\text { skillful and accurate. The teacher } \\
\text { guides students to practice a cross } \\
\text { step. H looks at her feet and walkson } \\
\text { her toes }\end{array}$ \\
\hline 9:34-10:00 & Practice group dances & $\begin{array}{l}\text { The group practice another nine group } \\
\text { dances together and H dances eight of } \\
\text { them. She doesn't practice one dance } \\
\text { because she hasn't learned it, so she } \\
\text { stands at the left side and watches the } \\
\text { other students. The teachers stand at } \\
\text { the front and correct the students' } \\
\text { actions from time to time }\end{array}$ \\
\hline 10:00-10:15 & Preparing to bak & $\begin{array}{l}\mathrm{H} \text { takes out an equipment box, dresses } \\
\text { in a pinafore, hat, gloves and mask. } \\
\text { She stands at a table with five or six } \\
\text { teammates }\end{array}$ \\
\hline $10: 15-10: 35$ & $\begin{array}{l}\text { The volunteer shows the students how } \\
\text { to make biscuits }\end{array}$ & $\begin{array}{l}\text { The volunteer teaches one student to } \\
\text { mix the ingredients with the mixer, } \\
\text { then puts the mixed ingredients in a } \\
\text { plastic bag, and pushes it into the } \\
\text { mold. H watches very carefully }\end{array}$ \\
\hline 10:35-11:05 & Making biscuits & $\begin{array}{l}\text { H asks her teammate to move the } \\
\text { mold closer to her side, this makes it } \\
\text { easier for her to add some chopped } \\
\text { walnuts to the mixture. The volunteers } \\
\text { help the students correct the way they } \\
\text { carry the bag. } \mathrm{H} \text { takes a filled-up bag } \\
\text { and adds the mixture to the mold } \\
\text { while her mom stands by to help her }\end{array}$ \\
\hline 11:05-11:30 & Washing the equipment & $\begin{array}{l}\text { The volunteer puts the tray into the } \\
\text { oven, at the same time, H and her } \\
\text { mom take the used equipment to the } \\
\text { bathroom for washing. The mother } \\
\text { points out the places where H didn't } \\
\text { wash properly and rinses the } \\
\text { equipment one more time herself }\end{array}$ \\
\hline 11:30-11:35 & Sharing the biscuits & $\begin{array}{l}\text { People share the biscuits and take } \\
\text { group pictures. H smiles and hands } \\
\text { her biscuit to the observer }\end{array}$ \\
\hline
\end{tabular}




\title{
Observation of Miss $\mathrm{H}$ at the Sunshine Workshop
}

\author{
Observation date: 8:30-15:00, January 3, 2017. \\ Observation place: Office of Quyang Subdistrict Sunshine Workshop in Hongkou \\ District, Shanghai. \\ Observer and writer: Shuwen Wang.
}

\begin{tabular}{|c|c|c|}
\hline Time & Content & Observed activities \\
\hline 9:00-9:10 & $\begin{array}{l}\text { The workers fold red envelopes in a } \\
\text { classroom. The atmosphere is rather } \\
\text { exciting, people are talking and } \\
\text { laughing }\end{array}$ & $\begin{array}{l}\text { H gives the observer a hug when they } \\
\text { see each other, then walks back to her } \\
\text { seat to make red envelopes. H puts } \\
\text { three bags together, aligns the lower } \\
\text { edge, then folds the seals at the same } \\
\text { time. Later, she separates the bags and } \\
\text { puts them in a plastic bag separately } \\
\text { and seals double-sided tape at the top } \\
\text { of the bag afterwards }\end{array}$ \\
\hline $9: 10-9: 12$ & $\begin{array}{l}\text { The teacher calls out the names for the } \\
\text { register }\end{array}$ & $\begin{array}{l}\mathrm{H} \text { answers when the teacher calls her } \\
\text { name. Then she puts packed red } \\
\text { envelopes together, but the high tower } \\
\text { of bags is leaning to one side, so } \mathrm{H} \\
\text { divides them into two groups when } \\
\text { she sees the problem }\end{array}$ \\
\hline $9: 12-9: 30$ & Making more red envelope & $\begin{array}{l}\text { H puts a rubber band on a bunch of } \\
\text { bags. H fetches a bunch of unfinished } \\
\text { bags from the front desk; after that, } \\
\text { she walks to the door and takes a look } \\
\text { outside. She takes out her water bottle } \\
\text { and puts it on the desk. She chats with } \\
\text { colleagues while making red } \\
\text { envelopes }\end{array}$ \\
\hline $9: 30-9: 40$ & & $\begin{array}{l}\text { H spots an odd-looking bag and } \\
\text { checks with the teacher, and she is } \\
\text { told it doesn't matter. Two bags of red } \\
\text { envelopes fall down from the desk } \\
\text { twice and H keeps picking them up. } \\
\text { She uses a rubber band to hold } 33 \\
\text { envelopes together. She usually turns } \\
\text { around and looks at the door while } \\
\text { working }\end{array}$ \\
\hline $9: 40-9: 55$ & & $\begin{array}{l}\text { A colleague comes over and } \mathrm{H} \text { greets } \\
\text { her }\end{array}$ \\
\hline $9: 55-10: 10$ & & $\begin{array}{l}\text { While some colleagues are chatting } \\
\text { across the aisle, H listens and looks at } \\
\text { them from time to time. She walks to } \\
\text { the front of the desk after she runs out } \\
\text { of plastic bags }\end{array}$ \\
\hline
\end{tabular}


(continued)

\begin{tabular}{|c|c|c|}
\hline Time & Content & Observed activities \\
\hline 10:10-10:20 & The teacher checks the red envelopes & $\begin{array}{l}\text { The teachers checks the number of } \\
\text { H's envelopes, but finds out she has } \\
\text { bundled over } 25 \text { bags together. So the } \\
\text { teacher helps her count the envelopes } \\
\text { and bundle them up again }\end{array}$ \\
\hline 10:20-10:40 & Making red envelopes & $\begin{array}{l}\text { When she hears a colleague's joke, } \mathrm{H} \\
\text { laughs away and joins in the } \\
\text { conversation, then she counts out } \\
\text { some new envelopes. The boy sitting } \\
\text { behind } \mathrm{H} \text { asks her for some plastic } \\
\text { bags, so H walks to the front desk to } \\
\text { fetch some bags for him }\end{array}$ \\
\hline 10:40-10:50 & & $\begin{array}{l}\text { H bundles up more finished envelopes } \\
\text { but the unfinished envelopes at the } \\
\text { front desk have run out. H stands next } \\
\text { to her seat for a while and gives an } \\
\text { extra rubber band to her colleagues. } \\
\text { She has a wander around the hall and } \\
\text { chats with some colleagues when she } \\
\text { returns }\end{array}$ \\
\hline $10: 50-11: 30$ & Lunch time & $\begin{array}{l}\mathrm{H} \text { and her colleagues start cleaning up } \\
\text { the desks when the lunch boxes arrive. } \\
\text { The lunch includes a set rice meal and } \\
\text { a bowl of tomato and egg soup }\end{array}$ \\
\hline 11:30-12:00 & Break time & $\begin{array}{l}\text { H has a slow walk in the park, which } \\
\text { is next to the Sunshine Workshop. She } \\
\text { chats with a colleague when they meet } \\
\text { in the park and watches somebody } \\
\text { play a handheld game console }\end{array}$ \\
\hline 12:00-12:40 & $\begin{array}{l}\text { People have a rest in the classroom } \\
\text { during the break. The curtains are } \\
\text { closed and the room becomes dark }\end{array}$ & $\begin{array}{l}\mathrm{H} \text { walks back to the room and takes a } \\
\text { rest }\end{array}$ \\
\hline 12:40-13:10 & Making red envelopes & $\begin{array}{l}\text { The afternoon duty is same as the } \\
\text { morning, making more red envelopes }\end{array}$ \\
\hline 13:10-13:20 & Break time & $\begin{array}{l}\text { When the unfinished red envelopes } \\
\text { run out, } \mathrm{H} \text { sorts out her finished red } \\
\text { envelopes and drinks some coffee } \\
\text { from a flask }\end{array}$ \\
\hline 13:20-13:50 & Making red envelopes & $\begin{array}{l}\text { More unfinished red envelopes come } \\
\text { in and H gets some as well. The } \\
\text { teacher repeats working tips. H } \\
\text { bundles up more envelopes after she's } \\
\text { worked for a while }\end{array}$ \\
\hline
\end{tabular}


(continued)

\begin{tabular}{l|l|l}
\hline Time & Content & Observed activities \\
\hline 13:50-15:00 & $\begin{array}{l}\text { The teacher lets the workers line up in } \\
\text { a queue in the hall to wait to weigh the } \\
\text { red envelopes they made today. } \\
\text { Teacher Han is in charge of weighing } \\
\text { and recording }\end{array}$ & $\begin{array}{l}\text { H carries her whole day's work to the } \\
\text { hall and joins the queue to wait for the } \\
\text { teacher to weigh it }\end{array}$ \\
\hline 15:00-15:15 & Duty off time & $\begin{array}{l}\text { H and several other workers play } \\
\text { musical instruments in the corner }\end{array}$ \\
\hline 15:15 & & $\begin{array}{l}\text { H leaves the workshop with a } \\
\text { colleague }\end{array}$ \\
\hline
\end{tabular}

Translated by Huili Meng Edited by Russell Murray

Open Access This chapter is licensed under the terms of the Creative Commons AttributionNonCommercial-NoDerivatives 4.0 International License (http://creativecommons.org/licenses/bync-nd/4.0/), which permits any noncommercial use, sharing, distribution and reproduction in any medium or format, as long as you give appropriate credit to the original author(s) and the source, provide a link to the Creative Commons license and indicate if you modified the licensed material. You do not have permission under this license to share adapted material derived from this chapter or parts of it.

The images or other third party material in this chapter are included in the chapter's Creative Commons license, unless indicated otherwise in a credit line to the material. If material is not included in the chapter's Creative Commons license and your intended use is not permitted by statutory regulation or exceeds the permitted use, you will need to obtain permission directly from the copyright holder.

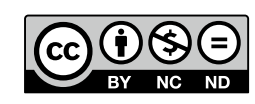

